\title{
PARTISIPASI POLITIK \\ (SEBUAH ANALISA PEMILUKADA PADA MASA PENDEMI COVID)
}

\author{
Muh. Saleh \\ Fakultas Hukum Universitas Gunung Rinjani \\ msaleh@ugr.ac.id
}

\begin{abstract}
Abstrak
Penelitian ini bertujuan untuk melihat lebih dekat perhelatan politik lima tahunan khusus pemilihan Gubernur dan Wakil Gubernur, Bupati dan Wakil Bupati, serta Walikota dan Wakil Walikota Tahun 2020 yang dilaksanakan pada masa pandemi covid-19. Penelitian ini membandingkan tingkat partisipasi pemilih dalam pemilukada pada 270 daerah di Indonesia sebelum pandemi covid 19 tepatnya pada Tahun 2015 dan pemilukada pada saat covid-19 melanda Indonesia yaitu Tahun 2020. Penelitian menggunakan metode kualitatif deskriptif dengan data sekunder yang diperoleh dari lembaga resmi pemerintah (KPU, Bawaslu), media masa baik koran maupun media sosial lainnya, serta hasil penelitian yang dilakukan oleh peneliti lainnya. Hasil penelitian menunjukkan bahwa pandemi covid-19 tidak berpengaruh pada tingkat partisipasi pemilih malah cenderung meningkat. Adapun alasan meningkatnya partisipasi antara lain pertama, masyarakat pemilih semakin percaya akan penyelenggara pemilu melaksanakan secara jujur dan adil; kedua semakin kompetitifnya para calon sehingga semakin masifnya kampanye yang dilakukan dan ketiga, melakukan mobilisasi kepada masyarakat.
\end{abstract}

Kata kunci: pemilihan, partisipasi, covid-19

\begin{abstract}
This study aims to take a closer look at the five-year political event specifically for the election of the Governor and Deputy Governor, Regent and Deputy Regent, as well as Mayor and Deputy Mayor in 2020 which was held during the COVID-19 pandemic. This study compares the level of voter participation in the post-conflict local election in 270 regions in Indonesia before the COVID-19 pandemic, to be precise in 2015 and the post-conflict local election when COVID-19 hit Indonesia, namely 2020. The study uses descriptive qualitative methods with secondary data obtained from official government institutions (KPU). , Bawaslu), mass media, both newspapers and other social media, as well as the results of research conducted by other researchers. The results of the study show that the COVID-19 pandemic has no effect on voter turnout, but tends to increase. The reasons for the increase in participation include, firstly, the voting community increasingly believes in the implementation of the election in an honest and fair manner; second, the more competitive the candidates are, so that the campaign will be more massive and third, mobilizing the community.
\end{abstract}

Keywords: election, participation, covid-19 


\section{PENDAHULUAN}

Pelaksanaan pemilihan Gubenur dan Wakil Gubernur, Bupati dan Wakil Bupati, serta Walikota dan Wakil Walikota dilaksanakan pada Tanggal 9 Desember 2020 terjadi pada saat Indonesia sedang menghadapi pandemi. Hal itu menimbulkan polemik yang terjadi di masyarakat luas. Polemik ini terjadi akibat semakin menyebarnya virus corona dan ditambah dengan semakin ketatnya aturan pemerintah berkaitan dengan mobilisasi warga. Pengetatan mobilisasi warga menjadi kebijakan kontroversi dengan dilangsungkannya perhelatan demokrasi di tingkat lokal dengan tetap digendakannya pelaksanaan pilkada walau sempat diundur yaitu sesuai dengan PKPU Tahapan Program dan Jadwal berlangsung tanggal 23 September 2020. Namun dengan alasan pemerintah bahwa pelaksanaan pemilukada dapat dilaksanakan dengan protokol kesehatan ketat. Pada akhirnya kebijakan in memberikan dampak pada anggaran pemilihan bertambah seperti menyediakan semua sarana prokes antara lain APD, Masker, hand sanitiser, sabun cuci tangan, pengecek suhu badan, dan luas TPS ditambah karena harus memperhatikan jarak serta menghindari terjadinya kerumunan. Sekalipun sempat diundur, pemerintah tetap keukeh melaksanakan pemilukada pada Tahun 2020 walaupun banyak lembaga masyarakat dan akademisi yang memberikan masukan agar pelaksanaan pilkada ditunda. Walaupun sejumlah kalangan masih diliputi kekhawatiran bahwa pelaksanaan tahapan kampanye calon hingga pemungutan suara di bilik suara atau tempat pemungutan suara (TPS) bakal menimbulkan cluster baru kasus Covid-19. Meskipun demikian, pelaksanaan pilkada berlangsung pada 9 Desember 2020 . Pemerintah, DPR bersama Komisi Pemilihan Umum (KPU), maupun Badan Pengawas Pemilu (Bawaslu) bersepakat membuat aturan baru agar proses Pilkada Serentak 2020 tetap berlangsung sesuai protokol kesehatan. Untuk Pilkada 2020, selain mengatur model kampanye, juga diatur model TPS untuk warga yang datang mencoblos.
Adapun alasan pemerintah tetap
melaksanakan pemilukada antara lain menurut Mahfud MD mengatakan bahwa Pertama, menjamin hak konstitusional rakyat untuk dipilih dan memilih sesuai dengan agenda yang telah diatur dalam undangundang dan atau dalam berbagai peraturan perundang-undangan, Kedua, pandemi Covid-19 belum bisa diketahui kapan akan berakhir. Karena itu, apabila Pilkada ditunda sampai Pandemi selesai, maka akan menimbulkan ketidakpastian; Ketiga, Presiden juga menurut Mahfud tidak ingin daerah yang menggelar Pilkada hanya dipimpin pelaksana tugas alias Plt dalam waktu bersamaan.Karena Plt itu tidak boleh mengambil kebijakan-kebijakan strategis. "Sedangkan situasi sekarang di dalam Covid19 kebijakan-kebijakan strategis yang berimplikasi pada penggerakan birokrasi dan sumber daya lain seperti dana itu memerlukan pengambilan keputusan dan langkah-langkah yang sifatnya strategis. Alasan ketiga menjadi inkonsistensi karena kasus yang sama akan terjadi massif dengan tidak dilakukannya revisi UU Nomor 10 Tahun 2016 karena dampak salah satunya adalah 272 daerah di Indonesia dipastikan akan dipimpin oleh Plt selama 1,5 s.d 2 tahun.

Komisi Pemilihan Umum (KPU) sebagai pelaksana teknis menyampaikan beberapa alasan pemilukada tetap dilaksanakannya pada Tahun 2020 antara lain pertama, KPU tentu melaksanakan amanat peraturan yang berlaku, untuk tetap melaksanakan agenda politik tersebut pemerintah menerbitkan Peraturan Pemerintah Pengganti UU(Perpu) Nomor 2 Tahun 2020 tentang Pilkada; sejalan dengan pemerintah alasan kedua, hingga saat ini tidak ada satu pihak pun yang bisa memastikan kapan pandemi Covid-19 berakhir; ketiga hak konstitusional memilih dan dipilih, periode lima tahunan pergantian kepemimpinan kapala daerah yang harus dilaksanakan; keempat, soal tata kelola anggaran, ini juga mesti harus dipikirkan (jika menunda ke tahun berikutnya); kelima, Indonesia sedang menuju adaptasi kebiasaan baru. 
Alasan normatif maupun praktis harus disampaikan secara logis kepada rakyat sebagai pemilik kedaulatan karena merekalah yang akan terdampak. Alasan yang dibangun juga mestinya mengandung tingkat konsisitensi yang tinggi karena trust masyarakat terhadap negara/pemerintah akhir-akhir ini terjadi kemerosotan seperti diungkap oleh hasil Survey LSI bahwa responden yang menyatakan sangat percaya terhadap TNI sebesar 25 persen dan cukup percaya sebesar 70 persen. Gubernur berada di peringkat kedua dengan yang menyatakan sangat percaya sebanyak 14 persen dan cukup percaya sebesar 77 persen. Adapun, wali kota/bupati berada di peringkat ketiga dengan pernyataan sangat percaya sebanyak 14 persen dan cukup percaya sebesar 76 persen. Tingkat kepercayaan presiden berada di peringkat keempat dengan yang menyatakan sangat percaya sebesar 20 persen dan cukup percaya sebanyak 68 persen. Di samping itu, tingkat kepercayaan masyarakat terhadap Komisi Pemberantasan Korupsi (KPK) menurun setiap tahunnya. Berada di peringkat keenam, dengan yang menyatakan sangat percaya sebesar 17 persen dan cukup percaya sebanyak 66 persen. Hasil LSI tersebut menemukan bahwa tingkat trust public presiden berada pada posisi 4 lebih rendah dari gubernur dan bupati yang berada pada tingkat 3 .

Penelitian ini membandingkan tingkat partisipasi pemilih dalam pemilukada sebelum pandemi covid 19 tepatnya pada Tahun 2015 dan pemilukada pada saat covid19 melanda Indonesia yaitu Tahun 2020 yaitu membandingkan pada pemilihan Gubernur dan Wakil Gubernur, Bupati dan Wakil Bupati, serta walikota dan wakil walikota di Indonesia dan fokus pada pemilihan di 7 kabupaten/kota di Nusa Tenggara Barat. Apakah ada perbedaan yang cukup mencolok dari kedua pemilkada tersebut. Pemilu pemilukada Tahun 2015 adalah Indonesia dalam keadaan normal tidak sedang dilanda pandemi, sementara pemilukada Tahun 2020 sebaliknya. kondisi tersebut telah memberi dampak pada tingkat pesimisme yang cukup tinggi dari para pengamat akan keberhasilan pemilukada karena adanya ketakutan orang keluar rumah sebagai dampak pandemi.
Apakah ada hubungan yang kuat antara covid dan tingkat partisipasi pemilih.

\section{METODE}

Penelitian ini menggunakan metode kualitatif diskriptif, yaitu dengan melakukan kajian terhadap data sekunder yang peroleh dari lembaga resmi pemerintah antara lain Komisi Pemilihan Umum dan Badan Pengawas Pemilu. Selain data di atas juga melakukan observasi/pengamatan langsung dan tidak langsung melalui pemberitaan koran maupun media sosial lainnya terhadap pelaksanaan pemilukada. Data sekunder lainnya peneliti memperoleh dari hasil penelitian yang dilakukan oleh akademisi, NGO (Non Government Organization) pemerhati pemilihan umum seperti Perludem, Netgrit, JaDI (Jaringan Demokrasi Indonesia), dan lain-lain. Pengolahan data dilakukan cara melakukan reduksi data dan analisis.

\section{PEMBAHASAN}

\section{Demokrasi dan Partisipasi}

Salah satu indikator keberhasilan pelaksanaan pemilu di Indonesia secara kuantitatif adalah tingkat partisipasi pemilih yang tinggi. Konteks pemilu di Indonesia ada problem klasik menjadi pertayaan secara akademis yaitu apakah partitipasi tinggi berbanding lurus dengan kualitas pemilu atau secara makro kualitas demokrasi itu sendiri. Menjawab pertanyaan itu tidak mudah karena berbagai faktor yang bisa dijadikan penyebab antara lain seperti yang dikemukakan oleh Robert Dahl sebagaimana dikutip oleh Neneng apakah proses pemilihan dilaksanakan dan memenuhi kriteria ideal demokrasi atau tidak, kreteria demokrasi ideal menurut Dahl adalah sebagai berikut: 1 . Effective participation (partisipasi efektif) yaitu adanya kesempatan yang sama dan setara untuk berpartisipasi; 2 . Voting equality at the decisive stage (kesetaraan pilihan) yaitu adanya jaminan penilaian setiap pilihan dihitung setara; 3. Enlightened understanding (pemahaman yang memadai) yaitu adanya pemahaman yang memadai untuk menemukan dan menentukan pilihan terbaik; 4. Control of the agenda 
(kontrol terhadap agenda) yaitu kesempatan untuk menentukan masalah politik; 5. Inclusiveness (inklusif) dan tidak adanya pengecualian untuk seluruh warga/pemilih. Lebih jauh (Susanne Pickel, et al) dalam penelitian yang dilakukan di Eropa mengenai kualitias demokrasi dalam perspektif masyarakat menyebutkan ada lima dimensi prosedural meliputi supremasi hukum, partisipasi, persaingan, dan akuntabilitas (vertikal dan horizontal) dan kedua dimensi substantif tersebut mencakup penghormatan terhadap kebebasan sipil dan politik serta kesetaraan.

Partisipasi politik merupakan ciri utama dari negara demokrasi. Demokrasi dinyatakan sebagai antitesa dari praktek monarki yang meletakan semua pengharapan pada seorang raja maupun kelompok berkuasa atau oligarkhi. Sebaliknya demokrasi dengan partisipasi aktif yang diperankan oleh sebagian atau seluruh lapisan masyarakat sesuai dengan interpretasi dan kebijakan yang diambil oleh masing-masing negara penganut demokrasi. Awal-awal penerapan demokrasi misalnya dilaksanakan oleh orang-orang dewasa bahkan perempuan tidak dilibatkan aktif dalam politik sehingga tidak seluruh masyarakat berpartipasi. Perkembangan penerapan demokrasi menjadi lebih luas bukan hanya warga negara dewasa berjenis kelamin laki-laki yang ikut dalam mengambil keputusan-keputusan strategis namun juga perempuan yang dikenal faham feminisme.

Partisipasi politik aktif juga ciri-ciri masyarakat modern sebagai bagian dari penerapan hak politik yang dibangun atas pondasi hak asasi manusia. Samuel P. Huntington mengatakan bahwa modernisasi politik memiliki beberapa ciri antara lain: pertama, modernisasi politik melibatkan adanya rasionalisasi kekuasaan, pergantian sejumlah besar pejabat-pejabat politik tradisional, etnis, dan keagamaan, kekeluargaan oleh kekuasaan nasional yang bersifat sekuler; kedua, pembangunan politik melibatkan diferensiasi fungsi politik baru dan pengembangan struktur khusus sebagai pelaksanan seluruh; dan ketiga adalah pembangunan politik ditandai oleh meningkatnya peran serta politik yang meliputi seluruh lapisan mamsyarakat. Dari hasil riset yang dilakukan Huntington menyakini bahwa dari ketiga bentuk modernisasi di atas, dalam realitas kehidupan politik terutama di negara-negara berkembang hanya mobilisasi dan partisipasi politik yang dapat berjalan sementara rasionalisasi, integritas, dan diferensiasi suram. Praktek suram ini dibuktikan dengan rezim militer otokratis dan pemerintahan partai tunggal, kudeta, dan revolusi, konflik etnis dan kerusuhan masal di mana modernisasi politik menuju modernisasi, modernisasi kecendrungan menuju kompetisi dan demokrasi dan pada akhirnya mengikis demokrasi itu sendiri.

Menurut Brigitte Geissel dkk. tantangan untuk mengukur kualitas demokrasi saat ini antara lain: pertama dan terpenting menyangkut perubahan dalam demokrasi nyata. Pengembangan masalah baru seperti globalisasi, mediatisasi, dan digitalisasi, meningkatkan partisipasi warga, ketidakpuasan dengan institusi demokrasi perwakilan, tumbuh heteregonitas etnis budaya dan ketidaksetaraan sosial, serta gejolak keuangan global mengakibatkan demokrasi kita cukup parah, termasuk di antara perubahan-perubahan resmi yang dihadapi demokrasi saat ini; kedua adalah kurangnya komunikasi antara ukuran kualitas demokrasi komunitas dan sub bidang penelitian demokrasi lainnya, seperti teori demokrasi dan filsafat, atau studi tentang perilaku politik dan sikap demokratis.

Berbicara partisipasi politik dalam pemilu dapat dikategorikan menjadi dua yaitu partisipasi politik dalam arti sempit dan dalam arti luas. Dalam arti sempit yakni bagaimana tingkat kehadiran pemilih ke tempat pemungutan suara untuk memberikan hak pilihnya secara langsung atau voter turnount sebagai bentuk partisipasi 
hakiki karena satu-satunya cara paling konkrit dalam mempengaruhi proses politik yang ada. Dalam arti luas adalah seluruh aktivitas pemilih dalam rangka ikut aktif dalam proses tahapan pemilu mulai dari pendataan pemilih, pencalonan, kampanye, datang ke tps, rekap, dan penetapan hasil. Partisipasi sangat erat kaitannya dengan bagaimana individu atau sumber daya manusia sebagaimana hasil hasil riset yang dilakukan oleh Brady et.al (1995) sebagaimana dikutip oleh Firki Disyacita, bahwa ada tiga sumber politik yang mempengaruhi minat individu warga untuk mengikuti pemilihan antara lain :

1. Uang, sumber daya ini dapat digunakan oleh individu sebagai sumbangan bagi calon dan partai politik maupun biaya akomodasi individu untuk datang ke tempat pemungutan suara atau menghadiri acara kampaye partai.

2. Waktu luang, berbeda dengan uang yang distribusinya relatif lebih bervariasi karena tingkat pendapatan antara individu berbeda, semua orang diasumsikan memiliki sumber daya waktu yang sama, yakin 24 jam sehari dan berkesempatan meluangkan waktu di akhir pekan.

3. Kecakapan warga Negara (civic skill). Kemampuan berorgasisasi dan berkomunikasi secara efektif baik lisan atau tertulis akan sangat menunjang kapasitas individu dalam melakukan aktivitas politik.

Lebih jauh Pizzorno membedakan partisipasi politik menjadi empat yaitu: pertama, partipasi politik professional, lazim dilakukan oleh politisi penuh waktu (full time) atau pejabat politik yang terlibat dalam sistem politik. Kedua, partisipasi kewarganegaraan misalnya mendukung kampaye politik, ikut serta dalam kelompok-kelompok asosiasi sukarela yang akui oleh negara, mengadakan lobi dengan pejabat publik, menjalin hubungan dengan politisi profesional melalui jaringan bisnis dan pertemanan; ketiga, partisipasi gerakan sosial, gerakan sosial memandang negara beserta instrumen kelengkapannya semata sebagai sumber daya untuk merealisasikan kehendak "mengubah dunia menjadi lebih baik"; keempat, partisipasi subkultur, tidak memiliki akses ke pembuat kebijakan publik baik di tingkat elit atau pusat.

Partisipasi politik adalah kegiatan seseorang atau sekelompok orang untuk ikut serta secara aktif dalam kehidupan politik, yaitu dengan jalan memilih pimpinan negara dan secara langsung atau tidak langsung mempengaruhi kebijakan pemerintah (public policy) (Budiardjo 1998:1). Merujuk Menurut Herbert Mc Closky (Budiardjo 2008:183-84), partisipasi politik adalah kegiatan-kegiatan sukarela (voluntary) dari warga masyarakat melalui cara mereka mengambil bagian dalam proses pemilihan penguasa, dan secara langsung atau tidak langsung, dalam proses pembuatan atau pembentukan kebijakan umum. Sedangkan, menurut (Ramlan 1992:140), partisipasi politik sebagai keterlibatan warga negara biasa dalam menentukan segala keputusan yang menyangkut atau mempengaruhi hidupnya.

Pada jenis partisipasi politik sebagai sebuah kegiatan dalam proses politik yang membutuhkan keterlibatan masyarakat. Semakin tinggi jumlah pemilih yang memberikan hak suara, maka semakin baik tingkat partisipasi politik di sebuah pemilu. Sebaliknya, semakin kecil jumlah pemilih, maka dapat diartikan semakin kecil tingkat partisipasi politiknya. Adapun jenisjenis partisipasi politik yaitu: 1) Partisipasi aktif, yaitu partisipasi yang berorientasi pada proses input dan output; 2) Partisipasi pasif, yaitu partisipasi yang berorientasi hanya pada output, dalam arti hanya menaati peraturan pemerintah, menerima dan melaksanakan saja setiap keputusan pemerintah; dan 3) Golongan putih (golput) atau kelompok apatis, karena menganggap sistem politik yang ada menyimpang dari yang dicita- citakan (Rahman 2007:288). 
Partisipasi politik masyarakat merupakan bentuk perwujudan negara demokrasi, di mana masyarakat dilibatkan langsung dalam Pemilihan Umum. Dalam hal ini, warga negara berperan penting dalam menseleksi pejabat-pejabat negara yang nantinya akan mengatur pemerintahan maupun tindakan-tindakan yang akan mereka ambil nantinya (Suryadi, 2007). Masyarakat sebagai aktor utama dalam pemilihan ini dituntut agar lebih partisipatif dalam segala bentuk tahapan penyelenggaraan Pemilukada.

\section{Pemilukada 2020}

$\mathrm{Di}$ tengah kontroversi dan pesimisme pengamat akan pelaksanaan pemilukada, pemerintah tetap kokoh melaksanakannya. Pemilukada yang semestinya dilaksanakan pada tanggal 23 September 2020 dilakukan penundaan dengan dikeluarkannya Peraturan Pemerintah Penggati UU Nomor 2 Tahun 2020. Terhadap penudaan tersebut KPU menunda 4 tahapan yaitu: pertama, tahapan rekruitmen badan penyelenggara di tingkat PPS tinggal menunggu pelantikan dan masa kerjanya, kedua, verifikasi faktual dukungan calon perseorangan; rekrutmen petugas pemutahiran data pemilih (PPDP) dan masa tugasnya serta pemutakhiran dan penyusunan daftar pemilih.

$$
\text { Isi Peraturan Pemerintah }
$$

Pengganti UU Nomor 2 Tahun 2020

Tentang Perubahan ketiga atas UndangUndang Nomor 1 Tahun 2015 Tentang Penetapan Peraturan Pemerintah Nomor 1 tahun 2014 Tentang Pemilihan Gubernur, Bupati dan Walikota, yakni mengubah pasal 120, kemudian melakukan penambahan terhadap dua pasal lainnya dengan menyisipkan pasal baru yaitu pasal 122A, 201V. pasal 120 diubah sehingga berbunyi “(1) Dalam hal pada sebagian wilayah Pemilihan, seluruh wilayah Pemilihan, sebagian besar daerah, atau seluruh daerah terjadi kerusuhan, gangguan keamanan, bencana alam, bencana nonalam, atau gangguan lainnya yang mengakibatkan sebagian tahapan penyelenggaraan Pemilihan atau Pemilihan serentak tidak dapat dilaksanakan, dilakukan Pemilihan lanjutan atau Pemilihan serentak lanjutan. (2) Pelaksanaan Pemilihan lanjutan atau Pemilihan serentak lanjutan sebagaimana dimaksud pada ayat (1) dimulai dari tahapan penyelenggaraan Pemilihan atau Pemilihan serentak yang terhenti.

Pasal 122A selengkapnya berbunyi:" (1) Pemilihan serentak lanjutan sebagaimana dimaksud dalam Pasal 120 dilaksanakan setelah penetapan penundaan tahapan pelaksanaan Pemilihan serentak dengan Keputusan KPU diterbitkan. Penetapan penundaan tahapan pelaksanaan Pemilihan serentak serta pelaksanaan Pemilihan serentak lanjutan sebagaimana dimaksud pada ayat (1) dilakukan atas persetujuan bersama antara KPU, Pemerintah, dan Dewan Perwakilan Rakyat. (3) Ketentuan lebih lanjut mengenai tata cara dan waktu pelaksanaan Pemilihan serentak lanjutan diatur dalam Peraturan KPU. Pasal 201A isinya "(1) Pemungutan suara serentak sebagaimana dimaksud dalam Pasal $2 \mathrm{Ol}$ ayat (6) ditunda karena terjadi bencana non alam sebagaimana dimaksud dalam Pasal 120 ayat (1). (2) Pemungutan suara serentak yang ditunda sebagaimana dimaksud pada ayat (1) dilaksanakan pada bulan Desember 2020. (3) Dalam hal pemungutan suara serentak sebagaimana dimaksud pada ayat (2) tidak dapat dilaksanakan, pemungutan suara serentak ditunda dan dijadwalkan kembali segera setelah bencana non alam sebagaimana dimaksud pada ayat (1) berakhir, melalui mekanisme sebagaimana dimaksud dalam Pasal 122A.

Penjelasan pasal 201A ayat 3 sebenarnya memberikan peluang untuk ditunda kembali manakala bencana non alam covid 19 belum berakhir, adapun bunyi penjelasan pasal 201A ayat 3 adalah "Pemungutan suara serentak pada bulan Desember 2020 ditunda dan dijadwalkan kembali apabila tidak dapat dilaksanakan karena bencana nasional 
pandemi Corona Virus Disease 2019 (COVID-19) belum berakhir'. Sampai Tahun 2021 Pandemi Covid 19 masih merebak bahkan tambah banyak, namun oleh pemerintah tetap dilakukan dengan alasan sangat berbeda dengan bunyi Perpu yakni tidak ada satupun lembaga yang bisa memastikan kapan pandemi ini berakhir, kalau memang begitu alasannya mengapa mesti harus ditunda, kesannya malah mengulur-ulur waktu. Apapun alasannya pemerintah tetap benar karena pada kondisi seperti saat ini sepertinya pemerintah pemegang kebenaran dan tidak ada seorang pun yang mampu membantahnya. Perlu diantipasi adalah jangan sampai semua kebijakan atau keputusan yang diambil pemerintah berlindung dibalik pandemi justru tidak produktif dan membuat masyarakat mengambang tidak memiliki kepastian informasi.

Perdebatan menarik soal penudaan ini adalah apakah tahapan pemilukada dilanjutkan atau dimulai dari tahapan awal. Kepastian jawaban ini menemui titik terang dengan dikeluarkannya PERPU Nomor 2 Tahun 2020 , dalam penjelasan pasal 122A ayat 2 bahwa "Yang dimaksud dengan "Pemilihan serentak lanjutan" termasuk di dalamnya terkait penetapan hari dan tanggal pemungutan suara serentak yang berubah akibat dari adanya penetapan penundaan pemilihan serentak". Membaca isi penjelasan tersebut lebih pada menggeser hari dan tanggal pemungutan suara, artinya tahapan, program, dan jadwal sebelum tetap diakui dan sementara tahapan selanjutnya menyesuaikan dengan perubahan hari dan tanggal tersebut.

Terlepas kontroversi tersebut, KPU sebagai penyelenggara teknis tidak ada alasan untuk tidak melaksanakan sehingga aturan turunan harus dibuat. Berdasarkan PERPU 2 Tahun 2020, KPU mengeluarkan Peraturan Komisi Pemilihan Umum Nomor 6 Tahun 2020 Tentang Pelaksanaan Pemilihan Gubernur dan Wakil Gubernur, Bupati dan Wakil Bupati serta Walikota dan Wakil Walikota Serentak Lanjutan dalam Kondisi Bencana Nonalam Corona Virus Desiase 19 (Covid-19) sebagaimana perubahan dengan PKPU Nomor 10 Tahun 2020 Tentang Perubahan Peraturan Komisi Pemilihan Umum Nomor 6 Tahun 2020 Tentang Pelaksanaan Pemilihan Gubernur dan Wakil Gubernur, Bupati dan Wakil Bupati serta Walikota dan Wakil Walikota Serentak Lanjutan dalam Kondisi Bencana Nonalam Corona Virus Desiase 19 (Covid-19). PKPU mengatur secara tehnis bagaimana mekanisme pelasakanaan pemilihan sesuai standar protokol kesehatan. Aturan teknis dimaksud misalnya dituangkan pada Pasal 5 (1) Pemilihan Serentak Lanjutan dilaksanakan dengan protokol kesehatan pencegahan dan pengendalian Corona Virus Disease 2019 (COVID-19) dengan memperhatikan kesehatan dan keselamatan penyelenggara Pemilihan, peserta Pemilihan, Pemilih, dan seluruh pihak yang terlibat dalam penyelenggaraan Pemilihan. (2) Aspek kesehatan dan keselamatan sebagaimana dimaksud pada ayat (1) dilakukan terhadap seluruh tahapan dengan paling kurang memenuhi prosedur sebagai berikut: a. penerapan prinsip keselamatan dan kesehatan kerja; b. secara berkala dilakukan rapid test atau Real Time Polymerase Chain Reaction (RT-PCR) terhadap anggota dan Sekretariat Jenderal KPU, serta anggota dan sekretariat KPU Provinsi, KPU Kabupaten/Kota, PPK, dan PPS dan/atau yang memiliki gejala atau riwayat kontak dengan orang terkonfirmasi Corona Virus Disease 2019 (COVID19); c. penggunaan alat pelindung diri berupa masker yang menutupi hidung dan mulut hingga dagu bagi anggota dan Sekretariat Jenderal KPU, serta anggota dan sekretariat KPU Provinsi, KPU Kabupaten/Kota, PPK, dan PPS yang sedang bertugas; $d$. penggunaan alat pelindung diri berupa masker yang menutupi hidung dan mulut hingga dagu, sarung tangan sekali pakai, dan pelindung wajah (face shield) bagi: 1 . PPS yang sedang melaksanakan 
verifikasi faktual dukungan Bakal Pasangan Calon perseorangan; 2. PPDP yang sedang melaksanakan Coklit; 3 . KPPS yang sedang melaksanakan Pemungutan dan Penghitungan Suara di TPS; e. penyediaan sarana sanitasi yang memadai pada tempat dan/atau perlengkapan yang digunakan untuk suatu kegiatan dalam pelaksanaan tahapan penyelenggaraan Pemilihan, berupa fasilitas cuci tangan dengan air mengalir dan sabun, disinfektan, dan/atau cairan antiseptik berbasis alkohol (hand sanitizer); f. pengecekan kondisi suhu tubuh seluruh pihak yang terlibat sebelum suatu kegiatan dalam tahapan penyelenggaraan Pemilihan dimulai, dengan menggunakan alat yang tidak bersentuhan secara fisik, dengan ketentuan suhu tubuh paling tinggi 37,30 (tiga puluh tujuh koma tiga derajat) celcius; g. pengaturan menjaga jarak bagi seluruh pihak yang terlibat dalam setiap tahapan penyelenggaraan Pemilihan paling kurang 1 (satu) meter; h. pengaturan larangan berkerumun untuk setiap kegiatan dalam masingmasing tahapan penyelenggaraan Pemilihan; i. pembatasan jumlah peserta dan/atau personel yang ditugaskan pada setiap kegiatan dalam pelaksanaan tahapan penyelenggaraan Pemilihan yang mengharuskan adanya kehadiran fisik; j. pembersihan dan disinfeksi secara berkala terhadap ruangan dan peralatan yang sering disentuh; $\mathrm{k}$. tidak menggunakan barang atau peralatan secara bersama; 1 . penapisan (screening) kesehatan orang yang akan masuk ke dalam ruangan kegiatan; m. sosialisasi, edukasi, promosi kesehatan dan penggunaan media informasi untuk memberikan pemahaman tentang pencegahan dan pengendalian penularan Corona Virus Disease 2019 (COVID19); dan pelibatan personel dari perangkat daerah yang menyelenggarakan urusan di bidang kesehatan atau tim dari Gugus Tugas Percepatan Penanganan Corona Virus Disease 2019 (COVID-19) di daerah masing-masing.
Teknis pelaksanaan pemilihan ini kemudian memunculkan anggaran yang cukup besar khusus pengadaan perlengkapan Protokol Kesehatan untuk seluruh petugas dari tingkat KPU sampai dengan tingkat KPPS. Jumlah anggaran yang harus disiapkan untuk Prokes sebagaimana dikemukakan oleh Menteri Keuangan Sri Mulyani bahwa Menteri Keuangan menjelaskan, sebelum ada COVID-19 anggaran Pilkada 2020 adalah sebesar Rp 15,23 triliun menggunakan APBD. Namun anggarannya ditambah sebesar Rp 5,23 triliun sehingga menjadi Rp 20,46 triliun. Kebijakan anggaran pemilukada berubah yang sebelumnya biaya pemilukada dianggarkan sepenuhnya dari APBD namun karena covid anggaran dibantu dari APBN khusus untuk pengadaan Prokes.

\section{Partisipasi Pemilukada Tahun 2020}

Potret pelaksanaan pemilukada untuk memilih Gubernur dan Wakil Gubenur di 9 Propinsi, Bupati dan wakil Bupati di 224 kabupaten, dan Walikota dan wakil walikota di 37 kota. Penelitian ini mengambarkan tentang bagaimana partisipasi dalam pemilihan Gubernur dan Wakil Gubenur, Bupati dan Wakil Bupati, dan Walikota dan Wakil Walikota yang dilaksanakan pada 9 Desember 2020. Apakah terjadi peningkatan atau penurunan tingkat partisipasi akibat dari covid 19.

Komisi Pemilihan Umum (KPU) memasang target $77,5 \%$ untuk partisipasi publik di 270 daerah dalam Pilkada serentak Desember 2020 meskipun diselenggarakan saat pandemi covid-19. "Target kita kali ini sama dengan sebelumnya (Pemilu 2019) $77,5 \%$ sebagaimana disampaikan Ketua KPU Arief Budiman. Untuk mencapai target tersebut, Arief mengatakan tidak jauh berbeda dengan apa yang dilakukan pihaknya pada penyelenggaraan sebelumnya. Namun, kali ini yang menjadi prioritas adalah kesehatan dan keselamatan baik pemilih, peserta maupun penyelenggara. Untuk meyakinkan masyarakat agar dapat 
menggunakan hak pilihnya, KPU akan mendesain tata cara pelaksanaan pemilihan terkait protokol kesehatan. Pihaknya pun selalu berkoordinasi dengan Kementerian Kesehatan dan Gugus Tugas.

Target KPU terhadap partisipasi pemilih pada Pemilukada 2020 sebanyak 77,5 persen tersebut menuai pesimisme dari perkumpulan untuk Pemilu dan Demokrasi (Perludem) Direktur Eksekutif Perludem Titi Anggraini mengatakan mendorong pemilih menggunakan hak pilih akan menjadi sulit pada masa pandemi virus Corona. "Di masa tidak pandemi pun cukup sulit mendorong pemilih menggunakan hak pilihnya di pilkada, dan bisa semakin sulit di tengah situasi pandemi yang kita hadapi.

Menurut Komisioner Komisi Pemilihan Umum (KPU) I Dewa Kade Wiarsa Raka Sandi sebagaimana disampaikan kepada media masa, bahwa tingkat partisipasi pemilih pada Pemilukada Tahun 2020 paling tinggi sejak tahun 2014. Seperti disampaikan dalam Rapat Koordinasi secara virtual terkait evaluasi kegiatan sosialisasi dan pendidikan pemilih dalam peningkatan partisipasi masyarakat pada pemilihan tahun 2020. "Secara nasional, tingkat partisipasi pemilih di tingkat nasional adalah 76,09 persen," jika dirinci, pada 2015, partisipasi pemilih dalam pemilu sebesar 69,35 persen. Kemudian 2017, naik menjadi 74,89 persen. Lalu, pada 2018, partisipasi pemilih sebesar 74,92 persen, sedangkan 2019 untuk pemilu presiden sebesar 81,97 persen, pemilu DPR 81,69 persen, dan pemilu DPD 82,52 persen.

Lebih detail Raka menyampaikan bahwa angka 76,09 rata-rata nasional jika dirinci khusus untuk pemilihan Gubenrur, Bupati dan Walikota sebagai berikut: pemilihan gubernur dan wakil gubernur, tingkat partisipasi rata-rata mencapai 69,67 persen. Sementara pada pemilihan bupati dan wakil bupati angka partisipasi pemilih rata-rata mencapai 77,52 persen. Sedangkan pada pemilihan wali kota dan wakil wali kota tingkat partisipasi pemilih rata-rata mencapai 69,04 persen. Dari data yang disampaikan oleh KPU menggambarkan bahwa Pemilukada tahun 2020 partisipasi cukup tinggi hampir mendekati rata-rata nasional yakni $77,5 \%$. Jika dibandingkan dengan 3 pemilukada sebelumnya yakni tahun 2015, tahun 2017 dan tahun 2018 angkanya cukup singnifikan yaitu 76,09 " meningkat $6,74 \%$ dari tahun 2015, meningkat $1,2 \%$ dari tahun 2017 , dan meningkat $1,17 \%$ dari tahun 2018 . Artinya dari data tersebut dapat disimpulkan bahwa partisipasi pemilih pada pemilukada tahun 2020 meningkat dari tahun-tahun sebelumnya. Menarik untuk dikaji adalah apa yang menjadi alasan mengapa pemilih antosias untuk hadir ke TPS. Pelaksanaan pemilukada ini juga diawali dengan pesimisme dari pegiat pemilu.

Tingginya tingkat partisipasi diapresiasi oleh pemerintah sebagaimana dikemukan oleh Mahfud MD bahwa pelaksanaan Pilkada Serentak 2020 selama ini dikhawatirkan sejumlah pihak lantaran kasus covid-19 masih tinggi. Selain itu, banyak ahli menyebut pelaksanaan pilkada akan menjadi klaster baru penyebaran Covid19. "Tapi berdasar itu kami mengatur protokol kesehatan dengan baik dan tingkat partisipasi alhamdulillah tinggi. Hampir 7 persen naiknya.

Apresiasi lain juga dikemukan oleh Menteri Dalam Negeri Tito Karnavian. Ia menilai, tingkat partisipasi Pilkada di tengah pandemi Covid-19 ini tinggi. Melampaui tingkat partisipasi pada pilkada 2015. Yaitu berada di angka 76 persen. "Tingkat partisipasi pemilih secara umum 76,09 persen, angka ini mendekati target 77,5 persen dari KPU dan ini melampaui partisipasi pemilih voters turn out pemilukada tahun 2015 sebagimana disampiakan dalam rapat di DPR,. Lebih lajut dia mengatakan, bahwa angka itu merupakan bukti keberhasilan Indonesia menggelar Pemilu di masa Pandemi. Dia membandingkan dengan Pemilu Amerika Serikat dengan tingkat 
partisipasi 66,9 persen yang merupakan tertinggi dalam 120 tahun terakhir. "Dengan angka tersebut menurut Menteri Dalam negeri salah satu keberhasilan bangsa Indonesia,. Dia juga membanggakan Pilkada 2020 merupakan pemilihan terbesar kedua seteah Amerika Serikat dari 96 pemilihan umum di seluruh dunia. Sebab, Indonesia memiliki potensi pemilih 100 juta orang dengan tingkat partisipasi hingga 76 persen. "Artinya hampir 77 juta pemilih yang hadir pada saat hari pemungutan suara se indonesia. Ini adalah election nomor dua terbesar di seluruh dunia."

Dari data yang dirilis oleh KPU bahwa Partisipasi pemilih pada Pilkada Serentak 2020 pada empat kabupaten di Provinsi Sulawesi Barat (Sulbar) peringkat satu nasional dan melampaui target KPU secara nasional."Partisipasi di Sulbar mencapai 87,70 persen atau tertinggi secara nasional, selain itu berhasil melampaui tingkat partisipasi pemilih secara nasional yang ditetapkan KPU RI, yaitu sekitar 77,5 persen," kata Koordiv Parmas SDM KPU Provinsi Sulbar Adi Arwan Alimin, di Mamuju, Selasa.

\section{Partisipasi pemilih di Propinsi Nusa Tenggara Barat}

Pemilukada pada 7 (tujuh) Kabupaten di Propinsi Nusa Tenggara Barat mengalami trend kenaikan dengan melakukan perbandingan terhadap pemilukada sama pada tahun yang berbeda seperti disampaikan di bawah ini.

Tabel 1.1. Tingkat Partisipasi Masyarakat pada Pemilihan Bupati dan Wakil Bupati serta Walikota dan Wakil Walikota Tahun 2015

\begin{tabular}{|c|l|c|c|c|}
\hline No. & Kabupaten/Kota & $\begin{array}{c}\text { Data Pemilih (DPT } \\
+ \text { DPTb) }\end{array}$ & $\begin{array}{c}\text { Pengguna Hak } \\
\text { Pilih }\end{array}$ & $\begin{array}{c}\text { Tingkat } \\
\text { Partisipasi } \\
(\mathbf{\% )}\end{array}$ \\
\hline 1 & Mataram & 298,406 & 164,640 & $55.17 \%$ \\
\hline 2 & Lombok Utara & 159,716 & 129,551 & $81.11 \%$ \\
\hline 3 & Lombok Tengah & 774,246 & 468,955 & $60.57 \%$ \\
\hline 4 & Sumbawa Barat & 92,689 & 72,652 & $78.38 \%$ \\
\hline 5 & Sumbawa & 327,277 & 248,007 & $75.78 \%$ \\
\hline 6 & Dompu & 163,643 & 136,290 & $83.28 \%$ \\
\hline 7 & Bima & 380,316 & 264,503 & $69.55 \%$ \\
\hline \multicolumn{4}{|c|}{ Tingkat Partisipasi (\%) } \\
\hline
\end{tabular}

Sumber : Data diolah dari KPU propinsi Nusa Tengggara Barat

Data pemilukada pada Tahun 2015 menunjukkan bahwa partisipasi pemilih cukup tinggi dengan rata-rata $71,98 \%$ atau hampir $73 \%$. Partisipasi tertinggi terjadi di Kabupaten Dompu dengan 83,28\% sedangkan terendah Kota Mataram dengan 55,17\%.

Tabel 1.2. Tingkat Partisipasi Masyarakat pada Pemilihan Serentak Tahun 2020

di 7 (Tujuh) Kabupaten/Kota se NTB

\begin{tabular}{|c|l|c|c|c|}
\hline No. & Kabupaten/Kota & $\begin{array}{c}\text { Data Pemilih (DPT } \\
\text { + DPTb) }\end{array}$ & $\begin{array}{c}\text { Pengguna Hak } \\
\text { Pilih }\end{array}$ & $\begin{array}{c}\text { Tingkat } \\
\text { Partisipasi } \\
\text { (\%) }\end{array}$ \\
\hline 1 & Mataram & 305,307 & 203,314 & $66.59 \%$ \\
\hline 2 & Lombok Utara & 173,888 & 151,994 & $87.41 \%$ \\
\hline 3 & Lombok Tengah & 760,809 & 534,565 & $70.26 \%$ \\
\hline 4 & Sumbawa Barat & 93,571 & 76,350 & $81.60 \%$ \\
\hline
\end{tabular}


Vol. 10. No. 1. Tahun 2022

\begin{tabular}{|l|l|c|c|c|}
5 & Sumbawa & 340,789 & 277,879 & $81.54 \%$ \\
\hline 6 & Dompu & 170,275 & 152,812 & $89.74 \%$ \\
\hline 7 & Bima & 368,451 & 296,876 & $80.57 \%$ \\
\hline \multicolumn{3}{|c|}{ Tingkat Partisipasi (\%) } & $\mathbf{7 9 . 6 7 \%}$ \\
\hline
\end{tabular}

Sumber : Data diolah dari KPU Propinsi Nusa Tengggara Barat

Dari data partisipasi pada Tahun 2020 di 7 (tujuh) kabupaten/kota di NTB menyajikan data terjadinya kenaikan dari Tahun 2015 yakni sekitar 7,69\% hampir 8\%. Data ini menunjukkan bahwa tingkat partisipasi pemilih di NTB berada di atas rata-rata nasional yakni $77,5 \%$. Data ini juga konsisten bahwa partisipasi tetap tinggi di Kabupaten Dompu dengan 89,74\% hampir $90 \%$ dan terendah Kota Mataram 66,59\% dan meningkat dari Tahun 2015. Data menarik dari pemilukada Tahun 2020 terhadap data pemilu Tahun 2015 di dua kabupaten, jumlah pemilih lebih rendah dari tahun sebelumnya yakni Kabupaten Lombok Tengah pada Tahun 2015 sebesar 774,246 pemilih sementara pada Tahun 2020 turun menjadi 760,809. Dan kabupaten Bima 380,316 pada Tahun 2015, tahun 2020 turun menjadi 368,451 . Data dua kabupaten ini memberikan kontribusi bagi meningkatnya partisipasi pemilih pada tahun 2020 jika dibandingkan pada Tahun 2015 karena jumlah pemilih mereka menurun. Penjelasan mengenai data pemilih ini menarik untuk dikaji penyebabnya. Namun demikian, penulis memiliki pengalaman mengenai fluktuasi pemilih terjadi karena beberapa alasan antara lain semakin berkualitasnya sistem deteksi data di pangkalan data KPU terutama berkaitan dengan data ganda baik ganda antardesa, antarkecamatan, antarkabupaten, antara propinsi bahkan data pemilih luar negeri sehingga setiap ada pemilu terjadi pengoresian data. Kedua adalah masifnya KPU dalam melakukan pendataan dengan kemampuan pendataan pada tingkat Pantarlih (PPDP) semakin baik dan disiplin. Kondisi ini juga sangat berpengaruh pada fluktuasi data. Yang ketiga biasanya juga berkaitan dengan kebijakan KPU tentang pemilih yang berada di luar negeri, apakah diikutkan dalam daftar pemilih atau tidak, saya menilai kebijakan KPU untuk tidak memasukkan mereka karena ketidakjelasan apakah yang bersangkutan pulang pada saat pemilihan atau tidak, jika dipastikan pulang maka dimasukkan dalam daftar pemilih tetap maupun tambahan, kalau tidak ada kepastian tidak dimasukkan, dengan ketentuan jika meraka pulang bisa menggunakan ktp atau paspor untuk memilih sesuai alamat yang tertera di KTP/Paspor. Dalam pemilukada bahwa tidak dikenal adanya Tempat Pemungutan Suara Luar negeri sehingga secara asas semestinya dimasukkan, tapi karena ada alternatif lain untuk diakomodir dalam pemilih tambahan yang menggunakan ktp menjadi alasan untuk tidak dimasukkan dalam daftar pemilih.

\section{Penyebab Angka Pertisipasi Naik}

Dari penelusuran yang dilakukan alasan pemilih datang ke tps pada hari pemungutan suara adalah : Peneliti dan pengamat politik Centre for Strategic and International Studies (CSIS). Arya Fernandes mengatakan bahwa angka partisipasi tinggi berdasarkan data Komisi Pemilihan Umum (KPU) angka partisipasi pilkada Tahun 2020 secara nasional cukup baik di atas prediksi banyak kalangan yang memperkirakan akan berada di bawah $65 \%$. Hal ini disebabkan sosialiasi terhadap protokol kesehatan di TPS berhasil dilakukan dengan baik. Sosialisasi ini memicu kepercayaan masyarakat di 270 daerah terhadap penyelenggara pemilu dan Kementerian Dalam Negeri. Kemudian terdapat kesadaran bersama untuk menerapkan protokol kesehatan dalam pilkada. Dan adanya kontestasi yang ketat di sejumlah wilayah yang membuat masyarakat datang ke TPS untuk memilih.

Berdasarkan hasil Survei Saiful Mujani Research and Consulting (SMRC) yang disampaikan oleh Direktur Saidiman Ahmad menyatakan bahwa tingginya partisipasi pemiliha 
disebabkan beberapa faktor antara lain: pertama, suksesnya mobilisasi pemilih untuk datang ke tempat pemungutan suara (TPS); kedua, publik tetap ingin punya kepala daerah yang mereka pilih secara langsung meski, ada Covid-19; Ketiga, mayoritas warga menganggap memilih pemimpin yang memperoleh mandat dari rakyat menjadi prioritas, meski tetap ada kekhawatiran tentang Covid-19. Keempat, mayoritas warga yakin bahwa protokol kesehatan dapat ditegakkan dalam Pilkada. kelima, mayoritas warga menilai Pilkada berlangsung dengan jurdil (jujur adil) sehingga suara mereka bermakna. Lebih lanjutnya Survei SMRC ini juga menunjukkan bahwa 86 persen warga menilai Pilkada berlangsung dengan jurdil. Lalu, sekitar 85 persen warga juga optimistis bahwa Pilkada akan melahirkan pemimpin yang membawa perbaikan di daerah.Bukan hanya itu, survey menunjukkan partisipasi warga desa lebih tinggi daripada masyarakat perkotaan pada saat Pilkada. Sebanyak 80 persen warga desa mengikuti Pilkada, sementara hanya 71 persen masyarakat perkotaan yang turut berpartisipasi. Selain data partitipasi tersebut juga menujukkan bahwa "Pada 9 Desember ketika pelaksanaan, kepatuhan menjaga jarak itu jauh di atas kepatuhan pada hari sebelum dan sesudah pemilihan. Pada 8 Desember kepatuhan menjaga jarak itu 77,61 persen, 10 Desember 77,04 persen. Tapi di 9 Desember itu 94,69 persen dan ini tidak pernah terjadi di hari-hari biasanya."

Sementara itu data yang dirilis oleh Bawaslu RI sebagaimana disampaikan oleh Anggota Badan Pengawas Pemilihan Umum (Bawaslu) RI, Ratna Dewi Pettalolo menyatakan bahwa "Kepatuhan tim kampanye secara umum pada tahapan kampanye masih dalam kondisi mengkhawatirkan atau belum baik tingkat kepatuhannya. Berdasarkan data Bawaslu, pelanggaran protokol kesehatan cukup tinggi," sampai dengan 12 Desember 2020, Bawaslu mencatat terdapat 4.250 dugaan pelanggaran pemilihan yang dilaporkan atau ditemukan oleh pengawas selama penyelenggaraan Pilkada. Pelanggaran tersebut seperti netralitas aparatur sipil negara, politik uang, penyalahgunaan kekuasaan, hingga kampanye di luar jadwal. "Ini menjadi catatan bahwa belum menjadi Pilkada yang sesungguhnya kita harapkan. Pilkada yang jujur, dan adil. Pilkada yang jujur adalah tanpa pelanggaran. Tapi ternyata angka pelanggaran di Tahun 2020 cukup tinggi,"

\section{KESIMPULAN}

1. Berdasarkan hasil pembahasan di atas dapat disimpukan bahwa angka partisipasi pada pemilihan Gubernur dan Wakil Gubernur, Bupati dan Wakil Bupati, serta Walikota dan Wakil Walikota Tahun 2020 meningkat cukup signifikan yakni $76,09 \%$ dan meningkat sekitar 6\% dari Tahun 2015 dengan pemilukada pada daerah yang sama;

2. Adapun faktor penyebab tingginya tingkat partisipasi tersebut antara lain: keberhasilan penyelenggara pemilu KPU sampai dengan tingkat KPPS mensosialisasikan protokol kesehatan; semakin tingginya kepercayaan publik terhadap peyelenggaraan pemilihan yang bersifat jujur dan adil; semakin tingginya tingkat kompetisi di daerah dengan mobilisasi yang sangat tinggi bagi pemilih;

3. Angka partisipasi yang tinggi juga dibarengi dengan tingkat pelanggaran protokol kesehatan cukup terutama pada tahapan kampaye tatap muka.

\section{DAFTAR PUSTAKA:}

Sahdan, Gregorius dan Muhtar dengan kontributor Fikri Disyacitta, Oligarki dan Klientelisme dalam Pilkada Serentak; dengan sub judul Partisipasi Politik Warga dalam Gerakan Desa dan Kampung Anti Politik Uang di Pilkada, The Indonesian power for Democracy (IPD), Yogyakarta 2020.

Geissel, Brigitte, Marianne Kneuer, and Hans Joachim Lauth. "Measuring the 
Vol. 10. No. 1. Tahun 2022

\begin{abstract}
Quality of Democracy: Introduction." International Political Science Review 37, no. 5 (2016): 571-79.

https://doi.org/10.1177/01925121166 69141.
\end{abstract}

Pickel, Susanne, Wiebke Breustedt, and Theresia Smolka. "Measuring the Quality of Democracy: Why Include the Citizens' Perspective?" International Political Science Review 37, no. 5 (2016): 645-55. https:

//doi.org/10.1177/019251211664117 9.

Sa'ban, L M A, and A A M Wijaya. "Menjaga Pemilukada Yang Demokratis Di Kota Baubau Melalui Peningkatan Partisipasi Politik Dan Pengawasan." Jurnal Politikom Indonesiana 5, no. 1 (2020): 69-84.

Wahid, Umaimah, Amin Aminudin, Hadiono Afdjani, Eko Sumardi, and Reni Rosita. "Penyuluhan Partisipasi Politik Dan Sosial Media Bagi Pemilih Pemula Pemilukada 2020 Di Sekolah Menengah Atas (SMA) Islam Cikal Harapan 01 Serpong Tangerang Selatan." RESONA: Jurnal Ilmiah Pengabdian Masyarakat 4, no. 2 (2020): 96-116.

Yuningsih, Neneng Yani, and Valina Singka Subekti. "Demokrasi Dalam Pemilihan Kepala Desa? Studi Kasus Desa Dengan Tipologi Tradisional, Transisional, Dan Modern Di Provinsi Jawa Barat Tahun 20082013." Jurnal Politik 1, no. 2 (2016). https://doi.org/10.7454/jp.v1i2.21.

Rahman, A. 2007. Sistem Politik Indonesia. Yogyakarta: Graha Ilmu Yogyakarta.

Ramlan, Surbakti. 1992. Memahami Ilmu Politik. Jakarta: Gramedia Widia Sarana Indonesia.

Budiardjo, Miriam. 1998. Partisipasi dan Partai Politik. Jakarta: Yayasan Obor Indonesia.
Budiardjo, Miriam. 2008. Dasar-Dasar Ilmu Politik. Jakarta: Gramedia Pustaka Utama.

Suryadi, Budi. (2007). Sosiologi Politik: Sejarah, Definisi dan Perkembangan Konsep. Yogyakarta: IRCiSoD

Huntington, Samuel P. Tertib Politik di Tengah Pergeseran Massa yang Diterjemahkan oleh Sahat Simmora dan Suryatim, Pt. Rajagrafindo Persada Jakarta, 2003 hal. 42-43.

Komisi Pemilihan Umum Propinsi Nusa Tenggara Barat, Data Partisipasi Pemilihan pada Pemilukada Tahun 2015 dan 2020, Mataram 2020.

Media Koran:

Sumber: https://mediaindonesia.com/politikdan-hukum/379529/partisipasipilkada-2020-tinggi-ini-penyebabnya

https://www.voaindonesia.com/a/partisipasiwarga-dalam-pilkada-2020-di-eracovid-19- meningkat/5704401.html

https://www.merdeka.com/politik/mendagritingkat-partisipasi-pemilih-pilkada2020-mencapai-76-persen.html

https://www.antaranews.com/berita/1897512/ partisipasi-pemilih-pilkada-serentak2020-di-sulbar-tertinggi-nasional

Artikel ini telah tayang di Kompas.com dengan judul "KPU: Partisipasi Pemilih dalam Pilkada 2020 Paling Tinggi Sejak 2014", Klik untuk baca: https://nasional.kompas.com/re $\mathrm{ad} / 2021 / 02 / 02 / 14195231 / \mathrm{kpu}-$ partisipasi-pemilih-dalam-pilkada2020-paling-tinggi-sejak-2014. Penulis : Sania Mashabi Editor Icha Rastika

Artikel ini telah tayang di Kompas.com dengan judul "KPU: Partisipasi Pemilih di Pilkada 2020 Capai 76,09 persen", Klik untuk baca: https://nasional.kompas.com/re ad/2020/12/31/18260221/kpupartisipasi-pemilih-di-pilkada-2020capai-7609-persen?page $=$ all. 
Vol. 10. No. 1. Tahun 2022

Penulis: Sania Mashabi Editor: Krisiandi

https://www.cnnindonesia.com/nasional $/ 2020$ 1214200614-32-582063/mahfudklaim-partisipasi-pemilih-pilkada2020-naik-7-persen

https://akurat.co/ada-biaya-protokol-covid19-anggaran-pilkada-2020-jadirp20,46-triliun

https://mediaindonesia.com/politik-danhukum/321499/pilkada-2020-kputarget-775-partisipasi-pemilih

https://news.detik.com/berita/d5059658/partisipasi-pemilih-pilkada2020-saat-pandemi-dinilai-sulitcapai-target-775

https://jdih.kpu.go.id/detailpkpu6a4d54587041253344253344

https://setkab.go.id/wpcontent/uploads/2020/05/PerpuNomor-2-Tahun-2020.pdf

https://perludem.org/2020/03/20/opsipenundaan-pilkada-oleh-titianggraini, 25 April 2021 jam 07.19

https://kompaspedia.kompas.id/baca/paparantopik/pilkada-langsung-serentaksejarah-dan-perkembangannya-diindonesia

Artikel ini telah tayang di Tribunnews.com dengan judul 4 Alasan Presiden Jokowi Tetap Lanjutkan Pelaksanaan Pilkada Serentak 2020, https://www.tribunnews.com/nasion al/2020/09/22/4-alasan-presidenjokowi-tetap-lanjutkan-pelaksanaanpilkada-serentak-2020. Penulis: Taufik Ismail Editor: Adi Suhendi

Artikel ini telah tayang di Tribunnews.com dengan judul 4 Alasan Presiden Jokowi Tetap Lanjutkan Pelaksanaan Pilkada Serentak 2020, https://www.tribunnews.com/nasiona 1/2020/09/22/4-alasan-presidenjokowi-tetap-lanjutkan-pelaksanaanpilkada-serentak-2020. Penulis: Taufik Ismail Editor: Adi Suhendi

Artikel ini telah tayang di Kompas.com dengan judul "Komisioner Ungkap 4 Alasan KPU Tetap Gelar Pilkada Saat Pandemi", Klik untuk baca: https://nasional.kompas.com/re ad/2020/06/21/22125671/komisioner -ungkap-4-alasan-kpu-tetap-gelarpilkada-saatpandemi?page=all.Editor: Krisiandi

Artikel ini sudah Terbit di Ayo Jakarta.com, dengan Judul Hasil Survei: Tingkat Kepercayaan Publik Terhadap Jokowi di Bawah Gubernur, pada URL

https://www.ayojakarta.com/read/20 21/02/22/31467/hasil-survei-tingkatkepercayaan-publik-terhadapjokowi-di-bawah-gubernur Penulis: Husnul Khatimah Editor : Husnul Khatimah 